\title{
LOSS OF HETEROZYGOSITY BY MITOTIC RECOMBINATION IN DIPLOID STRAIN OF Aspergillus nidulans IN RESPONSE TO CASTOR OIL PLANT DETERGENT
}

\author{
SOUZA-JÚNIOR, S. A., ${ }^{1}$ GONÇALVES, E. A. L., ${ }^{2}$ \\ CATANZARO-GUIMARÃES, S. A. ${ }^{3}$ and CASTRO-PRADO, M. A. A. ${ }^{1}$ \\ ${ }^{1}$ Universidade Estadual de Maringá, Departamento de Biologia Celular e Genética, Bloco H67, \\ Sala 21A, Av. Colombo, 5790, CEP 87020-900, Maringá, PR, Brazil \\ ${ }^{2}$ Universidade Estadual de Maringá, Departamento de Odontologia, \\ Av. Mandacaru, 1550, CEP 87083-170, Maringá, PR, Brazil \\ ${ }^{3}$ Universidade Sagrado Coração de Jesus, CPPG, Rua Irmã Arminda, 10-50, CEP 17044-520, Bauru, SP, Brazil \\ Correspondence to: Marialba A. A. Castro-Prado, Universidade Estadual de Maringá, \\ Departamento de Biologia Celular e Genética, Bloco H67, Sala 21A, Av. Colombo, 5790, \\ CEP 87020-900, Maringá, PR, Brazil, e-mail: maacprado@uem.br \\ Received June 10, 2003 - Accepted August 22, 2003 - Distributed November 30, 2004
}

(With 3 figures)

\begin{abstract}
Somatic recombination in heterozygous diploid cells may be a promotional agent of neoplasms by inducing homozygosity of defective genes. Tumor suppressor genes may in this way be completely suppressed in recombinant cells. In this work, the genotoxic effects of detergent derived from the castor oil plant (Ricinus communis) in heterozygous diploid cells of Aspergillus nidulans are evaluated. Previous studies have evaluated the application of this substance in endodontic treatments as an irrigating solution. The recombinogenic potential of the compound has been studied through the production of homozygous cells for nutritional markers riboA1, pabaA124, biAl, methA17, and pyroA4. Detergent was diluted to $1: 10,1: 20$, and 1:40, and morphologic alterations, delay in conidiophore development, and mitotic recombination occurrence were reported for the three dilutions. Although past studies have demonstrated the antimicrobial action of the detergent under analysis, our results revealed its cytotoxic effects and recombinogenic potential.
\end{abstract}

Key words: mitotic crossing-over, loss of heterozygozity, Ricinus communis, homozygotization index.

\section{RESUMO}

\section{Perda da heterozigose por meio da recombinação mitótica em linhagem diplóide de Aspergillus nidulans em resposta ao detergente derivado do óleo da mamona}

A recombinação somática em células diplóides heterozigotas pode atuar como agente promotor de neoplasias por induzir homozigose de genes deletéreos. Por meio desse processo, genes supressores de tumores podem ser completamente suprimidos em células recombinantes. O presente trabalho avaliou a genotoxicidade do detergente derivado do óleo da semente da mamona (Ricinus communis) em células diplóides heterozigotas do fungo filamentoso Aspergillus nidulans. Trabalhos anteriores avaliaram a aplicação dessa solução no tratamento de canais radiculares como líquido irrigador. O potencial recombinagênico desse composto foi estudado pela origem de células homozigotas para os marcadores nutricionais: riboA1, pabaA124, biA1, metA17 e piroA4. A solução, diluída em 1:40, 1:20 e 1:10, induziu alterações morfológicas e atraso no desenvolvimento dos conidióforos da linhagem UT448//UT196 e aumento nas freqüências de recombinação mitótica. Embora trabalhos anteriores relatem a atividade 
antimicrobiana da solução em estudo, nossos resultados evidenciam a citotoxicidade e o potencial recombinagênico dessa substância.

Palavras-chave: crossing-over mitótico, perda de heterozigozidade, Ricinus communis, índice de homozigotização.

\section{INTRODUCTION}

The development of malignant neoplasms may be stimulated by environmental factors (physical or chemical agents) or induced by factors related to the host (genetic inheritance, sex, and age) (Ringer \& Schniper, 2000).

In heterozygous diploid cells, somatic recombination may be a promotional agent of neoplasms by inducing homozygosis of deleterious genes. Tumor suppressor genes may thus be completely suppressed in recombinant cells. The products of these genes act mainly during the cell division process by controlling the cell cycle and/or the programmed cell death process (apoptosis) (Fearon \& Volgelstein, 2000).

In mitosis, segregation of sister chromatids constitutes a basic process of cell division, in which each cell receives a copy from each chromatid. Homologous chromatids can eventually establish contact among themselves, which leads to the process of mitotic exchange when chromosomic breaks occur. The segregation of a paternal and a recombinant chromatid in the same mitotic polar region originates homozygous cells for genes located in the distal position of the exchange point (Zimmermann, 1971).

Mitotic crossing-over, known for decades to occur in Drosophila melanogaster as well as in several other organisms such as Aspergillus nidulans, Aspergillus niger, and mammals, is considered a common process in diploid cells (Roper \& Pritchard, 1955; Debets et al., 1993; Beumer et al., 1998).

In recent years a constant search has been underway for biocompatible and organically harmless materials for use in dental procedures (Costa et al., 1997). At the same time, the castor bean (Ricinus communis), which is a common tropical climate plant with excellent potential for oil production, guarantees a large-scale supply of polyol and fatty acid prepolymers (Ferreira et al., 1999).

Obtained by hydraulic seed-pressing, the oil is the precursor of a polymer that is probably applicable in reconstructing and repairing bone defects. Besides, it contains a detergent compound of fatty esters with bactericidal properties, because of which studies have been carried out to evaluate results of using this detergent as an irrigating solution in endodontic treatment. High biocompatibility seems to be indicated by the results. Antibacterial activity of the detergent in chemical-mechanical preparation of teeth with necrotic pulp was shown to be comparable to that of $0.5 \%$ sodium hypochlorite solution (Ferreira et al., 1999, 2002; Mantesso, 2000).

But studies have also demonstrated the toxic effects of castor bean seeds on animals (Brito \& Tokarnia, 1997). Furthermore, castor oil contains a large amount of proteins such as globulins, proteases, and a special type of toxalbumin named ricin (Jones, 1947).

Taking into account both the toxic effects of the extract derived from castor bean seeds, and that a product with castor oil plant detergent in its composition is commercially available in Brazil (Ferreira et al., 2002), the present work evaluates genotoxicity of this detergent in diploid cells of Aspergillus nidulans.

\section{MATERIAL AND METHODS}

\section{Strains}

The strains UT448 and UT196 derived from Utrecht stocks (Holland) were used to form the UT448//UT196 diploid strain: a) UT448: wA2 (II) white conidia; riboAl, pabaA124, biAl (I), with requirements of riboflavin, $p$-aminobenzoic acid, and biotin, respectively; AcrAl (II) resistance to acriflavin; b) UT196: yAl (I) yellow conidia; methA17 (II); pyroA4 (IV), with requirements of methionine and pyridoxine, respectively.

\section{Culture media and genetic techniques}

The culture media were: minimal medium (MM) and complete medium (CM) (Pontecorvo et al., 1953; Roper \& Pritchard, 1955). The solid medium was prepared with $1.5 \%$ of agar. General methodology followed previous reports (Roper, 1952; Pontecorvo et al., 1953). 


\section{Cytotoxicity evaluation of castor oil plant detergent}

Conidia of diploid strain (UT448//UT196) were inoculated into the center of $\mathrm{CM}$ plates (control) and $\mathrm{CM}+$ detergent in the following dilutions: $1: 10$, 1:20, and 1:40. A total of 12 plates were inoculated and incubated at $37^{\circ} \mathrm{C}$. Colony diameters were measured with a ruler once a day during four days. Results were analyzed using Student's $t$ test for $\mathrm{p}<$ 0.05 .

\section{Conidia treatment}

The $2.10^{7}$ conidia from the diploid strain were treated with castor oil plant detergent in dilutions $1: 10,1: 20$, and 1:40. After 8 hours, conidia were washed and three suspensions were prepared with saline solution $(0.8 \%)$. The suspensions were diluted to $10^{-2}$, and $0.1 \mathrm{ml}$ of each solution was inoculated into MM plates. Eight colonies from the diploid strain were isolated and inoculated in MM plates for the recombinagenesis test.

\section{Measurement of mitotic crossing-over}

Diploid segregants were submitted to spontaneous haploidization in CM. Only segregants that failed to originate mitotic sectors, demonstrating genetic stability, were selected (Franzoni et al., 1997).

For determining the homozygosity index (HI), conidia of each haploid sector were individually transferred to 25 definite positions ( $5 \times 5$ pattern) on $\mathrm{CM}$ plates to establish their phenotypes. If the castor oil plant detergent induced mitotic crossingover in the original diploid, only heterozygous (+//- or $-/ /+$ ) or homozygous (+//+) diploids would develop in MM. Nutritional markers would segregate in a 4+: 2- proportion. On the other hand, if the detergent did not induce crossing-over, the proportion would be 4+: 4-. It is important to remember that the initial selection process (in MM plates) limited the growth of homozygous diploids -//- (Fig. 1). When the homozygosity index $[\mathrm{HI}=$ number of prototrophic (+) segregants/number of auxotrophic (-) segregants] for a determined marker is 2.0 , recombination has occurred. The HI values higher than 2.0 indicate the occurrence of more than one mitotic crossing-over event for a given marker. After phenotypic analyses of the haploid mitotic segregants, $\mathrm{HI}$ is determined for each nutritional marker (Pires \& Zucchi, 1994). Results are compared by Yates' continuity corrected chi-square test for $\mathrm{p}<0.05$.

\section{Cytological analyses}

Conidia of diploid strain were inoculated over dialysis membranes supported by solidified complete medium + castor oil plant detergent diluted to $1: 10,1: 20$, and 1:40. Plates were incubated at $37^{\circ} \mathrm{C}$ and samples, stained with lactophenol cotton blue, were examined under the light microscope after 24 hours.

\section{RESULTS}

The HI values obtained in the tests carried out with diploid strains of Aspergillus nidulans treated with castor oil plant detergent are shown in Table 1. Results indicate the occurrence of mitotic recombination in the intervals between the markers under analysis and the centromere, underscoring the recombinogenic potential of the studied detergent.

In the three tested dilutions, mycelia growth of the diploid strain in castor oil plant detergent actually decreased when compared to mycelia growth in the absence of this substance. Toxic effects of the detergent during the growth of fungi were evidenced (Fig. 2).

Cytological analyses also showed aberrant conidiophores, with bifurcations and vacuoles, as well as conidiophores with malformed vesicles and a reduced number of metulae and phialides (Fig. 3).

\section{DISCUSSION}

The genotoxicity of castor oil plant detergent was evaluated by its capacity to induce mitotic crossing-over in a diploid strain of A. nidulans. Three dilutions of the detergent were tested in a UT448//UT196 diploid strain $(1: 10,1: 20$, and 1:40). The viability of the treated conidia varied between $2.0 \%$ and $5.0 \%$; the 1:10 dilution was the most toxic (results not shown). The HI values (Table 1) indicate mitotic crossing-over occurrence between the markers of the treated diploid strain. The recombinagenic effect of detergent derived from castor bean oil may be related to cell-cycle interference of the substance, which stimulates mitotic recombination occurrence.

Because of its parasexual cycle, the filamentous fungus Aspergillus nidulans constitutes an excellent system for studying mitotic crossing-over, since its cells spend a substantial part of their cell cycle in the $\mathrm{G} 2$ phase during the germination period 
(Bergen \& Morris, 1983). Therefore, the existence of two copies of each chromosome during that period of the cell cycle significantly favors a mitotic recombination event (Osman et al., 1993).

Aspergillus nidulans colonies cultivated in the presence of the detergent derived from castor oil in 1:10 dilution showed intense morphologic alterations, e.g., malformed vesicles and reduced number of metulae, phialides, and conidia. The alterations were less in 1:20 and 1:40 dilutions (Fig. 3).

Delay in mycelial growth demonstrates castor oil plant detergent interference in the asexual cycle of Aspergillus nidulans, confirming the toxic effects of the substance.
No crossing-over
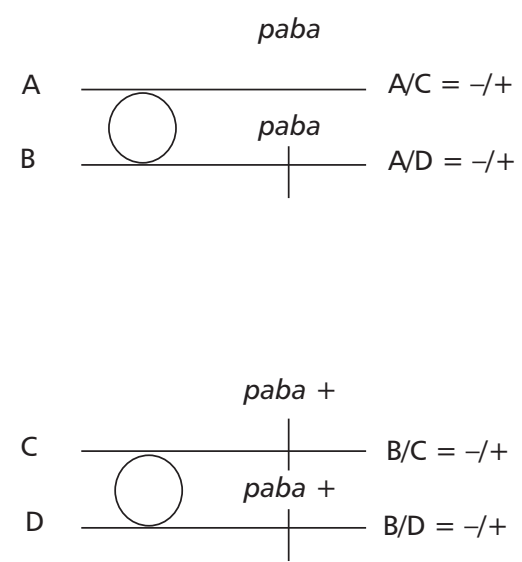

$4+: 4-$

Crossing-over

A
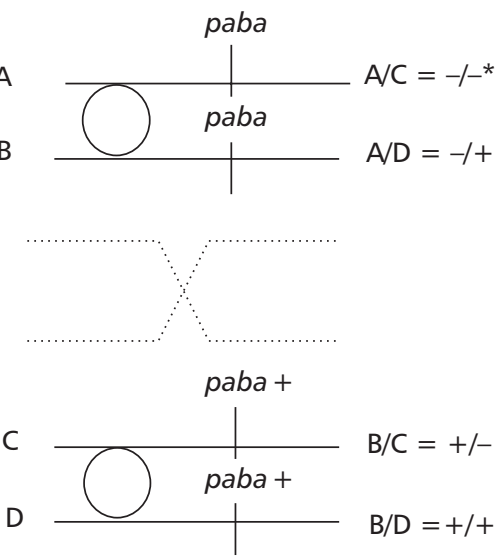

$4+: 2-$

Fig. 1 - Origin of recombinant diploid segregants through mitotic crossing-over. *Not grown in MM.

TABLE 1

Homozygotization Indexes (HI) of nutritional markers from diploid strain UT448//UT196 exposed to detergent. In dilutions 1:10 (diploid 1), 1:20 (diploids 2-4) and 1:40 (diploids 5-7).

\begin{tabular}{|c|c|c|c|c|c|c|c|c|c|c|c|c|c|c|c|c|}
\hline \multirow{2}{*}{$\begin{array}{c}\text { Genetic } \\
\text { markers }\end{array}$} & \multicolumn{2}{|c|}{ Control } & \multicolumn{2}{|c|}{ Diploid 1} & \multicolumn{2}{|c|}{ Diploid 2} & \multicolumn{2}{|c|}{ Diploid 3} & \multicolumn{2}{|c|}{ Diploid 4} & \multicolumn{2}{|c|}{ Diploid 5} & \multicolumn{2}{|c|}{ Diploid 6} & \multicolumn{2}{|c|}{ Diploid 7} \\
\hline & N. seg. & HI & N. seg. & HI & N. seg. & $\mathrm{HI}$ & N. seg. & $\mathrm{HI}$ & N. seg. & HI & N. seg. & HI & N. seg. & HI & N. seg. & HI \\
\hline ribo+ & 33 & 1.2 & 32 & $4.0 *$ & 139 & 1.9 & 133 & 2.0 & 90 & 1.6 & 40 & 2.0 & 96 & $3.5^{*}$ & 68 & 1.3 \\
\hline ribo & 27 & & 8 & & 73 & & 67 & & 57 & & 20 & & 27 & & 54 & \\
\hline paba+ & 34 & 1.3 & 32 & $4.0 *$ & 141 & 2.0 & 132 & 1.9 & 90 & 1.6 & 33 & 1.2 & 96 & $3.5^{*}$ & 84 & 2.2 \\
\hline paba & 26 & & 8 & & 71 & & 68 & & 57 & & 27 & & 27 & & 38 & \\
\hline$b i+$ & 33 & 1.2 & 31 & $3.4 *$ & 142 & 2.0 & 131 & 1.9 & 90 & 1.6 & 33 & 1.2 & 95 & $3.4^{*}$ & 84 & 2.2 \\
\hline$b i$ & 27 & & 9 & & 70 & & 69 & & 57 & & 27 & & 28 & & 38 & \\
\hline meth+ & 33 & 1.2 & 32 & $4.0 *$ & 139 & $1.9 *$ & 154 & $3.3^{*}$ & 113 & $3.3 *$ & 43 & $2.5^{*}$ & 91 & $2.4^{*}$ & 74 & 1.5 \\
\hline meht & 37 & & 8 & & 73 & & 46 & & 34 & & 17 & & 38 & & 48 & \\
\hline pyro+ & 31 & 1.1 & 21 & 1.1 & 118 & 1.2 & 102 & 1.0 & 85 & 1.4 & 36 & 1.5 & 81 & 1.7 & 58 & 1.0 \\
\hline pyro & 29 & & 19 & & 94 & & 98 & & 62 & & 24 & & 48 & & 64 & \\
\hline
\end{tabular}

*Significantly different from control. Yates' continuity correct chi-square test, $\mathrm{p}<0.05$. 


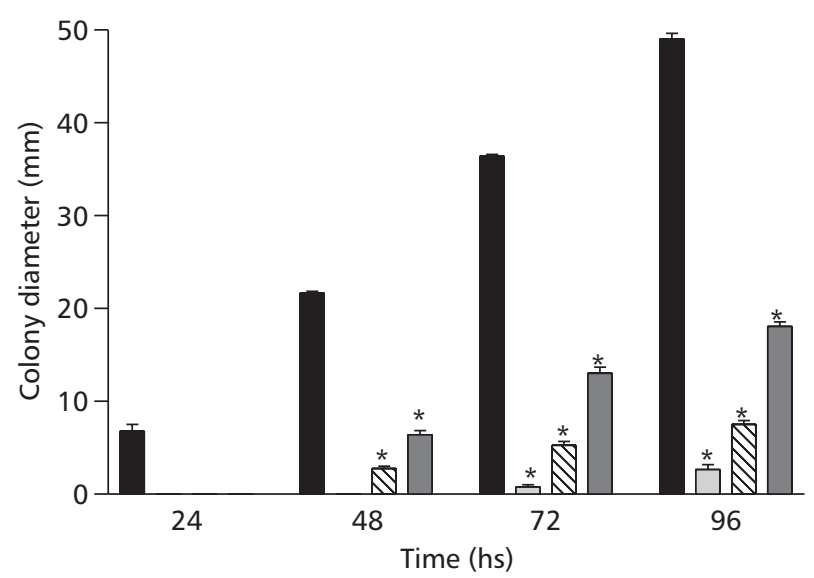

Contro

Dilution of $1: 10$

MIII Dilution of $1: 20$

Dilution of $1: 40$

Fig. 2 - Growth of UT448//UT196 diploid strain in complete medium + castor oil plant detergent in dilutions 1:10, 1:20, and 1:40. *Significantly different from control, Student's $t$ Test, $\mathrm{p}<0.05$.
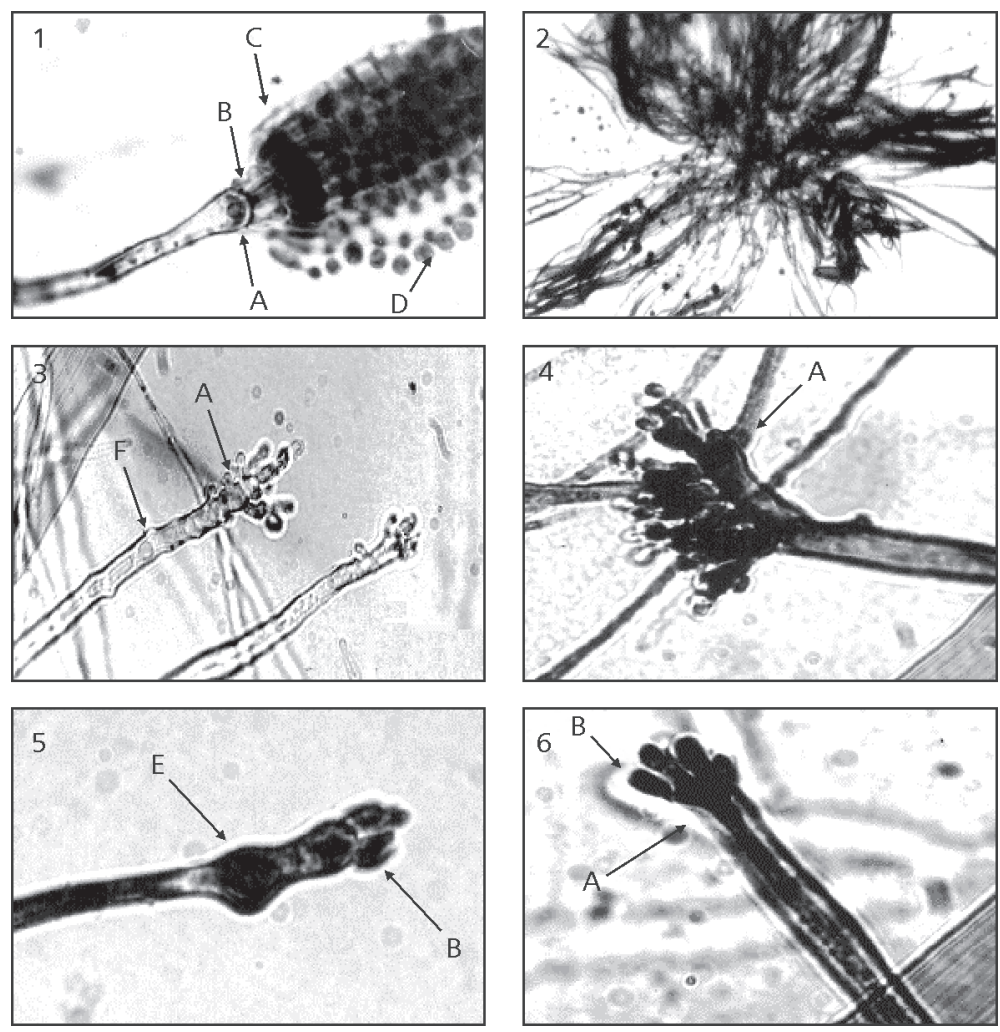

Fig. 3 - (1) Normal Conidiophore of UT448//UT196 strain obtained in CM. (2) Micelial growth of diploid strain in presence of detergent in 1:10 dilution. $(3,4)$ Malformed vesicle and conidiophore with branches obtained with castor oil detergent in 1:20 dilution. $(5,6)$ Malformed conidiophore stalk and vesicle, and reduced number of metulae obtained with castor oil detergent in 1:40 dilution. A, vesicle; B, metulae; C, phialide; D, conidia; E, conidiophore stalk; F, vacuole. Vesicle diameter: $10 \mu \mathrm{m}$. 
Although previous reports have demonstrated the bactericidal effect of the castor oil plant detergent, its recombinagenic potential and cytotoxic effects, demonstrated in this study, argue against its use as an irrigating solution in endodontic treatments. Further studies should be carried out to characterize the effects of this detergent on mammalian DNA.

Acknowledgements - Thanks are expressed to Dr. Gilberto Orivaldo Chierice (Institute of Chemistry of São Carlos, USP, Brazil) for supplying the castor oil; to Sonia A. de Carvalho and Luzia A. S. Regasse for technical assistance; and to God, once again, for supporting our efforts.

\section{REFERENCES}

BERGEN, G. G. \& MORRIS, N. R., 1983, Kinetics of the nuclear division cycle of Aspergillus nidulans. J. Bacteriol., 156: 155-160.

BEUMER, K. J., PIMPINELLI, S. \& GOLIC, K. G., 1998, Induced chromosomal exchange directs the segregation of recombinant chromatids in mitosis of Drosophila. Genetics, 150: $173-188$.

BRITO, M. F. \& TOKARNIA, C. H., 1997, Intoxicação experimental pelas sementes trituradas de Ricinus communis (Euphorbiaceae) em coelhos. Pesq. Vet. Bras., 17: 1-7.

COSTA, C. A. S., MARCANTONIO, R. A. C., HEBLING, J., TEIXEIRA, H. M. \& KURAMA, E. M., 1997, Biocompatibilidade do polímero de poliuretana vegetal derivada do óleo da mamona em estudo comparativo com cimento de óxido de zinco e eugenol. Avaliação histopatológica de implantes subcutâneos de ratos. Odonto 2000, 1: 44-48.

DEBETS, F., SWART, K., HOWKSTRA, R. F. \& BOS, C. J., 1993, Genetic maps of eight linkage groups of Aspergillus niger based on mitotic mapping. Curr. Genet., 23: 47-53.

FEARON, E. R. \& VOLGELSTEIN, B., 2000, Tumor suppressor gene defects in human cancer, pp. 67-87. In: R. C. Bast, D. W. Kufe, R. E. Pollock, R. R. Weischselbaum, J. F. Holland \& E. Frei, Cancer Medicine. BC Decker Inc., Hamilton, Ontario.
FERREIRA, C. M., BONIFÁCIO, K. C., FRÖNER, I. C. \& ITO, I. Y., 1999, Evaluation of the antimicrobial activity of three irrigating solutions in teeth with pulpal necrosis. Braz. Dent. J., 10: 115-121.

FERrEIRA, C. M., ROSA, O. P. S., TORRES, A. S., FERREIRA, F. B. A. \& BERNARDINELLI, N., 2002, Activity of endodontic antibacterial agents against selected anaerobic bacteria. Braz. Dent. J., 13(2): 118-122.

FRANZONI, M. M. G., CASTRO-PRADO, M. A. A. \& GEBARA, J. S., 1997, On the recombinogenic activity of norfloxacin in a diploid strain of Aspergillus nidulans. Cytologia, 62: 39-45.

JONES, D. B., 1947, Proteins of the castor bean - their preparation, properties, and utilization. Journal of the American Oil Chemistry Society, 24: 247-251.

MANTESSO, A., 2000, In vitro evaluation of a new intracanal irrigating solution derived from Ricinus communis. Anais da XVI Reunião Anual da SBPqO, 1: 18.

OSMAN, F., TOMSETT, B. \& STRIKE, P., 1993, The isolation of mutagen-sensitive nuv mutants of Aspergillus nidulans and their effects on mitotic recombination. Genetics, 134: 445-454.

PIRES, L. T. A. \& ZUCCHI, T. M. A. D., 1994, A new method to detect potential genotoxic agents using mitotic crossing-over in diploid strains of Aspergillus nidulans. Braz. J. Gen., 17: 371-376.

PONTECORVO, G., ROPER, J. A., HEMMONS, L. M., MACDONALD, K. D. \& BUFTON, A. W. J., 1953, The genetics of Aspergillus nidulans. Advances in Genetics, 5: 141-238.

RINGER, D. P. \& SCHNIPER, L. E., 2000, Principles of cancer biology, pp. 25-30. In: R. C. Bast, D. W. Kufe, R. E. Pollock, R. R. Weischselbaum, J. F. Holland \& E. Frei, Cancer medicine. BC Decker Inc., Hamilton, Ontario.

ROPER, J. A., 1952, Production of heterozygous diploids in filamentous fungi. Experientia, 8: 14-15.

ROPER, J. A. \& PRITCHARD, R. H., 1955, Recovery of complementary products of mitotic crossing-over. Nature, 175: 639 .

ZIMMERMANN, F. K., 1971, Genetic aspects of carcinogenesis. Biochm. Pharm., 20: 985-995. 